accidents, not the unforeseeable outcome of their deliberate efforts. That the technical theme won in the end is due not only to the greater sophistication of its proponents but also to the fact that the metaphysical question is unanswerable - which does not, however, eliminate it. Fears and hopes were vastly exaggerated and opinions about the unforeseeable polarized. Scientists on both sides of the public debate spent for years large proportions of their time not in research but in lobbying Congress and state governments, and in writing and speaking for the public media. Unused though they were to political manoeuvrings, those on Watson's side did pretty well. The NIH guidelines were significantly relaxed, as were GMAG's procedures, and the scientists, bruised but relieved, could return to their work. The issues raised by the episode remain, however.

During these eventful years some suggested that all genetic manipulation should be stopped. Even if it were desirable, this cannot be done. Short of nuclear catastrophe the acquisition of scientific knowledge is an irreversible process; for better or worse we have to live with it. The question is how? Watson is against all regulations, as is Norton Zinder who believes that recombinant DNA research is ". . . as safe as most other biological research and safer than that dealing with a number of very dangerous microorganisms . . ." (p.201). These scientists defend their wish to be left alone by pointing to other uncontrolled hazards and regard the good sense of the scientific community as sufficient guarantee of safety. Such arguments are suspect because they are so clearly interwoven with selfinterest. Richard Novick expressed this best when he declared himself unable to distinguish between the following two statements as bases for his belief that the experiments were safe:

1. I am convinced they are not dangerous, and therefore it is ok to do them; or 2. I have convinced myself they are safe precisely because I want to do them! [p.149].

If the whole episode demonstrates one thing it is that there is no harmonious scientific community interested only in the advancement of knowledge and its benefits for mankind. Yes, there is passionate commitment to driving forward their breath-taking discoveries; but there is also ambition, jealousy, lack of foresight, moral ambiguity and arrogance in these scientists, and there is absolutely no reason to assume that they are any better in these matters than we of a lesser breed. It seems reasonable to require that some people whose self-interest is not vested in genetic manipulation should be involved in monitoring these experiments.

This, of course, is easier said than done. Lay participation, as in the United States at the height of the controversy, may only have strengthened the irrational and antiscience trends in society. It has not bridged the enormous gap in knowledge between the scientists and the general public. Lay participation as in England is token participation, symbolic rather than real. What can a lay person do, when scientists disagree about the containment category of a given experiment, but side with the one with the bluer eyes? Perhaps such frustration about one's technical incompetence will be mitigated when issues arise about which we all are equally competent or incompetent. One such issue, though not restricted to genetic manipulation, arises over the possibility of cloning human beings. Sir Peter Medawar (p.246) considers this well nigh impossible but reports that Jacques Monod did not. John Maynard Smith agrees with Monod.

\section{Irish rocks reviewed}

\section{W.S. McKerrow}

A Geology of Ireland. Edited by C.H. Holland. Pp.335. Hbk ISBN UK 0-70730269-2, ISBN US 0-470-27247-3; pbk ISBN 0-7073-0308-7. (Scottish Academic Press/ Halsted: 1981.) Hbk £27.50, \$49.95; pbk $£ 15$.

MosT geologists know that the British Isles contain rocks of unusually diverse types and ages for such a small part of the world. Ireland is as varied and complex as any other part of these islands; thus it is good to be provided with a concise review of Irish geology. In the final chapter (on the history of Irish geology) we are reminded of the lean years between 1914 and 1947 when significant advances were made in only two branches of geology in Ireland: Tertiary igneous petrology, and Pleistocene stratigraphy and geomorphology. This was followed by a revival in which both academic and economic geologists, mainly from outside Ireland, played a part. In the past two decades Irish geologists (living in Ireland, if not all of Irish descent) have performed an increasing amount of the geological research in Ireland. The ten contributors to the book have each spent much or all of their professional careers in Ireland, eight in Dublin and two in Belfast, and each of them is an authority in his own field.

In the preface, Professor Holland points out that a lot has happened in our understanding of Irish geology since Charlesworth's Historical Geology of Ireland was published by Oliver \& Boyd in 1963, but this book follows a very different pattern. While Charlesworth attempted to refer to every paper (good, bad and indifferent) on Irish geology, and thus is still a good source for the older literature, Holland has been much more selective; and while Charlesworth covered the whole country single-handed, Holland has gathered a team for the task. The authors each possess an individual style and range of expertise,
The great merit of Watson and Tooze's book is that it displays the arguments on all sides. It offers only personal, not general solutions to fundamental questions. The worst sequel to this whole exciting episode would be if young scientists decided to withdraw into their ivory towers; the best if it were regarded as a rehearsal for things to come, from which to learn how illprepared scientists and the public still are to face the issues that confront them jointly and how to improve their relations while there is time.

Marie Jahoda is Professor Emeritus of Social Psychology and Consultant to the Science Policy Research Unit, University of Sussex. For two years she was a member of GMAG, representing the public interest.

but the editor has clearly stamped his authority on the book. Each chapter is a very readable, well-illustrated, resumé of our knowledge and understanding of Irish geology today. (Or is it yesterday? Most chapters make little reference to work later than 1976, and most fail to include references later than 1978).

In addition to the chapters on stratigraphy, there are sections on tectonics, igneous activity and geophysics, which might be expected in such a general review. More unexpected, especially to those geologists who regard drift as a nuisance, are the fascinating chapters on the Quaternary, which extend well past the $5,000 \mathrm{BP}$ date of the first Irishmen, and are almost continuous, with no more than small non-sequence, through to the final, historical chapter.

Economic geology has played, and is continuing to play, a major part in Irish life, from the Bronze Age copper mines of County Cork to the search for offshore oil today. The review includes clear descriptions of the major metal mines, together with a summary of opinions on the possible origins of the ore bodies. The section on oil and natural gas contains a useful summary of the offshore geology around Ireland, from the Celtic Sea to the Rockall Plateau.

A Geology of Ireland will prove to be a useful book for the student who wishes to obtain a general view of Irish geology; it should therefore find a place in every geology library. But the research geologist, academic or economic, may not find all that he requires in the text, or, more seriously, in the references - the editor has limited them to a level which I would consider to be lower than satisfactory. The Geological Society of London Special Reports on the correlation of rocks in the British Isles do provide many of the missing references, but some of these are now even more out of date than the references listed in the book.

W.S. McKerrow is a Lecturer in the Department of Geology at the University of Oxford. 